Potravinarstvo Slovak Journal of Food Sciences

vol. 15, 2021, p. 536-545

https://doi.org/10.5219/1619

Received: 20 April 2021. Accepted: 17 May 2021.

Available online: 28 June 2021 at www.potravinarstvo.com

(C) 2021 Potravinarstvo Slovak Journal of Food Sciences, License: CC BY 4.0

ISSN 1337-0960 (online)

\title{
INCREASING THE RETURN ON EQUITY BY FINANCIAL LEVERAGE IN SUGAR BEET FARMS IN SLOVAKIA
}

\author{
Tomáš Rábek, Andrea Boháčiková, Ivan Holúbek, Zuzana Strápeková
}

\begin{abstract}
The paper evaluates and analyses selected financial ratios of a set of farms in Slovakia in 2017. The farms are divided into two groups (sugar beet producers and sugar beet non-producers). The data used for the analysis were obtained from the National Bank of Slovakia (NBS) over the period 2009 - 2017 and the database of the Ministry of Agriculture and Rural Development of the Slovak Republic (MARD SR). Farmers generally achieve a low level of return on equity. In the paper, we analyze the development of interest rates and measure the potential effect of financial leverage, which can increase the profitability (return on equity) of the farms. Moreover, we test the statistically significant difference of selected ratios between the group of producers and non-producers of sugar beet in Slovakia. In 2017, the return on equity of sugar beet producers in Slovakia reached lower results in comparison to sugar beet non-producers. The differences in return on equity are explained by the lower level of equity per ha and thus higher indebtedness of non-producers of sugar beet.
\end{abstract}

Keywords: farm; sugar beet; profitability; indebtedness; financial leverage

\section{INTRODUCTION}

Before September 30, 2017, there existed quotas for sugar beet production in the EU member states. They represented restrictions for sugar beet production in individual EU member states (MS) and reduced competition between the countries. Nowadays, neither sugar beet producers nor sugar beet growers are constrained by quotas. It increases the risk of a potential bankruptcy of sugar companies in less competitive areas, and continually affects the cultivation of sugar beet, which has not been a marketable commodity for a long-term period (Tóth and Pokrivčák, 2019). Sugar prices have been developing very specifically and dynamically in recent years. In the EU member states, due to the deregulation of the sugar market, the production increased approximately by 25\% between 2016/2017 and 2017/2018. This situation, combined with the increase in isoglucose production, growing imports from the ACP countries, and changes in consumer preferences, puts significant pressure on the price, which stays at the low

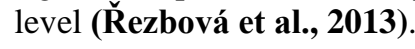

To sustain competitiveness, it is necessary to look for effective ways to increase the profitability of the sugar beet business, not only to produce it. One option is to optimize the capital structure of a company, to achieve an optimal ratio between the financial sources of a company, to increase the profitability of a business. Moreover, it increases the market value of a company.

In the paper, the basic financial ratios (profitability ratios, debt ratios) of sugar beet producers in Slovakia are assessed and compared to other businesses (sugar beet non- producers). Moreover, the practical application of decision - making process whether to increase the indebtedness of the company is assessed. The outcome of managers' decisions may have a positive impact on the return on equity. The increase in the return on equity and the growth of the market value of a company is the primary goal of each business in the market economy.

In the theory, there are several approaches how to optimize the financial structure of a company. We consider the authors Modigliani and Miller (1958) to be pioneers in capital structure optimization. In the Compromise theory (Brealey and Myers, 1992), the authors combined the $\mathrm{M}$ $\mathrm{M}$ model with real market conditions and defined the optimal indebtedness as a compromise between the interest tax shield and the cost of financial distress. Other theories of optimal capital structure are the Theory of hierarchical order of authors Robischek and Myers (1966) or the Signalling model from Ross (1977). The traditional approach, the Theory of the U Curve, is also popular; according to Bartošová (2005), it accepts the validity of individual differences between companies in the level of indebtedness and claims, that the companies should have as much debt as they can handle themselves.

The theory of the $\mathrm{U}$ - curve, in comparison to the classical approach, admits that the growth of a company's indebtedness increases the risk of creditors, who compensate it by raising interest rates. Shareholders also compensate for the increase in risk by requiring a higher return on their capital. Therefore, a company can borrow at the normal interest rate until creditors start to consider the 
debt ratio as an indicator of increasing their risk. Subsequently, the weighted average costs of capital (WACC) start to increase as creditors provide additional loans only at a higher interest rate. Shareholders will also demand a higher return on invested capital due to growing debt risk. It means that till a certain moment, the total cost of capital decreases as the indebtedness increases, and then it begins to increase, which graphically reminds the shape of the "U" curve. The optimal capital structure is the point, where the cost of capital WACC reaches the minimum value. At this point, the highest market value of the company is achieved, too (Tóth et al., 2019). However, the theory deals with the problem of determining the cost of equity. Similarly, the other theories face several different problems in practical application.

An interesting approach to capital structure optimization is the theory of authors Neumaierová and Neumaier (1996). The advantage of their approach is the ability to replace the data on the cost of equity with the data from a company's financial statements. The main objective is to provide managers with a model on how to decide about the appropriate level of indebtedness in a company.

However, it is important to realize that the negative aspect of increased debts in a company is the increased financial risk, and consequently, the threat of financial distress, which may result in the bankruptcy of the company (Hrdý and Krechovská, 2013).

\section{Practical implications}

The increased share of debt can have a positive effect on the return on equity. However, on the other hand, the increased share of borrowings is connected with increased interests. Interests reduce the share of profits for the investors and cause the decrease of the interest burden ratio and thus cause the decrease of return on equity (ROE).

In the literature, Slovak authors sometimes use the ratio ROI (return on investments) for expressing the return on total capital. However, in foreign literature, it is rather used for measuring the profitability of a particular investment. Therefore, it is preferable to use the abbreviation BEP (basic earning power), since this indicator represents the ratio of EBIT to total capital or assets (total assets = total capital) (Tóth et al., 2019). The indicator is suitable especially in spatial comparison of companies, but also for comparison over time. The ratio does not take into account different taxation and different capital structure of companies.

The problem of the capital structure of agricultural companies in Slovakia, as well as the effect of financial leverage in agricultural financing, has been analyzed in various scientific papers. The main findings have been that only a few companies could increase their indebtedness, mainly due to the low level of return on total capital (Čierna and Rábek, 2012). Conversely, companies that achieved higher values of the ROE, have been able to take the advantage of the favorable leverage effect (Rábek et al., 2013a). The period since 2008 has been characterized by a decline in interest rates in Slovakia, driven by a general decline in central bank interest rates in the EU. The reduction of costs of debt increases its attractiveness and leads to an increase in the share of debt in financing the needs of a company (Rábek et al., 2013b). The return on equity of agricultural companies has been generally at a low level. In almost half of the agricultural companies, the level of ROE did not exceed 3\%. However, there were $25 \%$ of companies on the market with a return on equity of over 10\% (Rábek et al., 2018).

\section{Scientific hypothesis}

Sugar beet is one of the most efficient crops from the perspective of production and energy potential (Janíček, 2019; Holúbek, 2011). Sugar beet farms achieve higher average ROA (return on assets), but the result has not been statistically proved in each year of authors' analysis (Tóth et al., 2017).

However, sugar beet producers can be expected to achieve higher ROE than non-producers. Sugar beet cultivation is technically demanding and requires initial financial investment. As stated before, debt is considered a cheaper source of financing. Therefore, it is assumed that sugar beet producers will use more borrowed capital and will be more indebted.

In the paper, we test the following hypotheses:

H0: There is no statistically significant difference in the return on equity between the group of sugar beet producers and the group of sugar beet non-producers.

H1: There is a statistically significant difference in the return on equity between the group of sugar beet producers and the group of sugar beet non-producers.

H0: There is no statistically significant difference in indebtedness between the group of sugar beet producers and the group of sugar beet non-producers.

H1: There is a statistically significant difference in the indebtedness between the group of sugar beet producers and the group of sugar beet non-producers.

\section{MATERIAL AND METHODOLOGY}

To assess the level of return on equity and indebtedness of agricultural companies in Slovakia in 2017, individual data about sugar beet producers were used. Data for evaluation of selected ratios were obtained from information letters of MARD SR (Ministry of Agricultural and Rural Development of the Slovak Republic). Agricultural companies were classified into 2 groups, sugar beet producers and non-producers. The company was considered as a producer of sugar beet if the ratio of the sugar beet harvesting area to the total agricultural area LPIS (Land Parcel Identification System) was non - zero. Authors Tóth et al. (2019) used a similar classification criterion based on the share of sugar beet harvesting area to the LPIS area in their analysis, classifying farms into 4 groups.

Companies with a negative value of equity were excluded from the analysis. The final data set consisted of 1417 agricultural companies in the primary sector in 2017. The companies were legal entities operating on 1.298 thous. hectares (ha) according to LPIS. From the overall data set, 132 companies belonged to the sugar beet producers with a sugar beet harvesting area of 18.5 thous. ha out of the total area 215.785 thous. ha. The sugar beet production thus covered $8.6 \%$ of the harvesting area on average.

The parallel, matrix, and pyramidal systems of financial and economic ratios are used not only in business practices but also in scientific research, as confirmed by several scientific studies. One of the most widely used decompositions of ratios is the Du Pont's decomposition of return. 


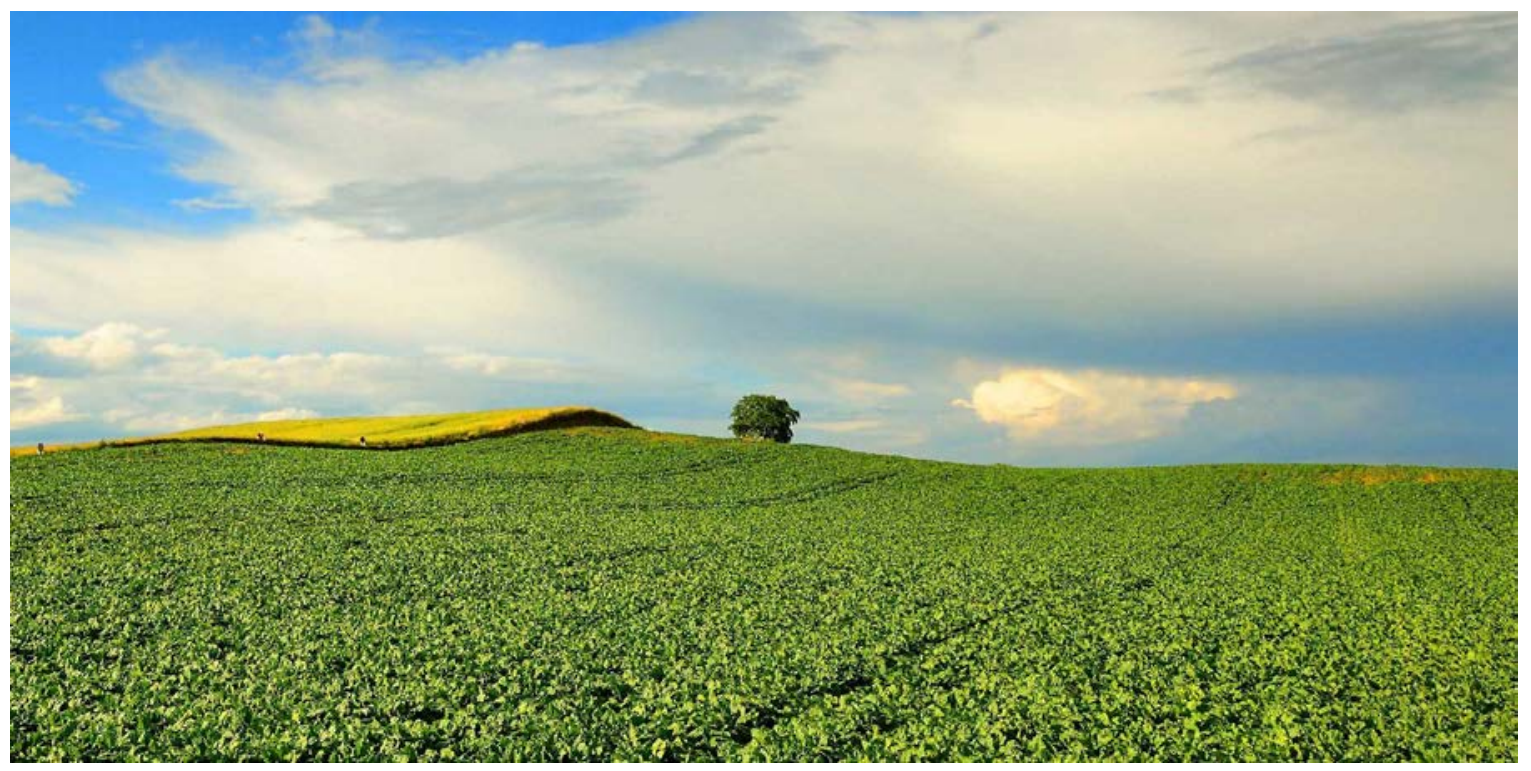

Figure 1 Sugar beet fields in Slovakia. Source: Pol'noinfo (2021).

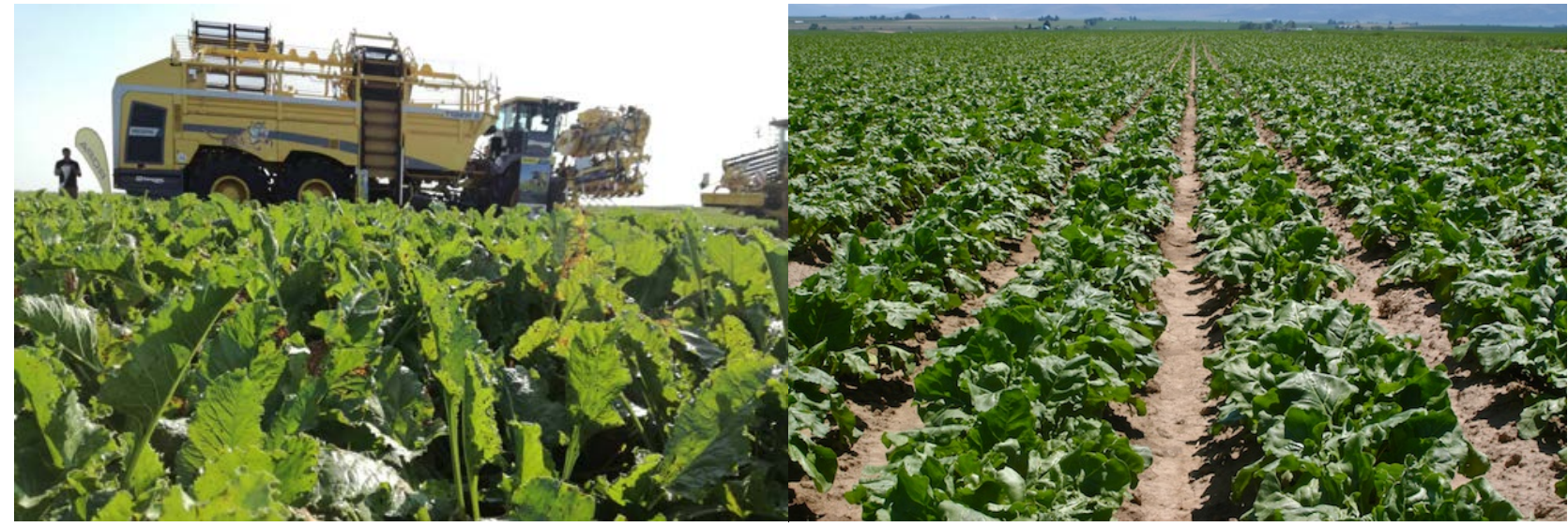

Figure 2 Sugar beet cultivation in Slovakia. Source: Pol'noinfo (2021).

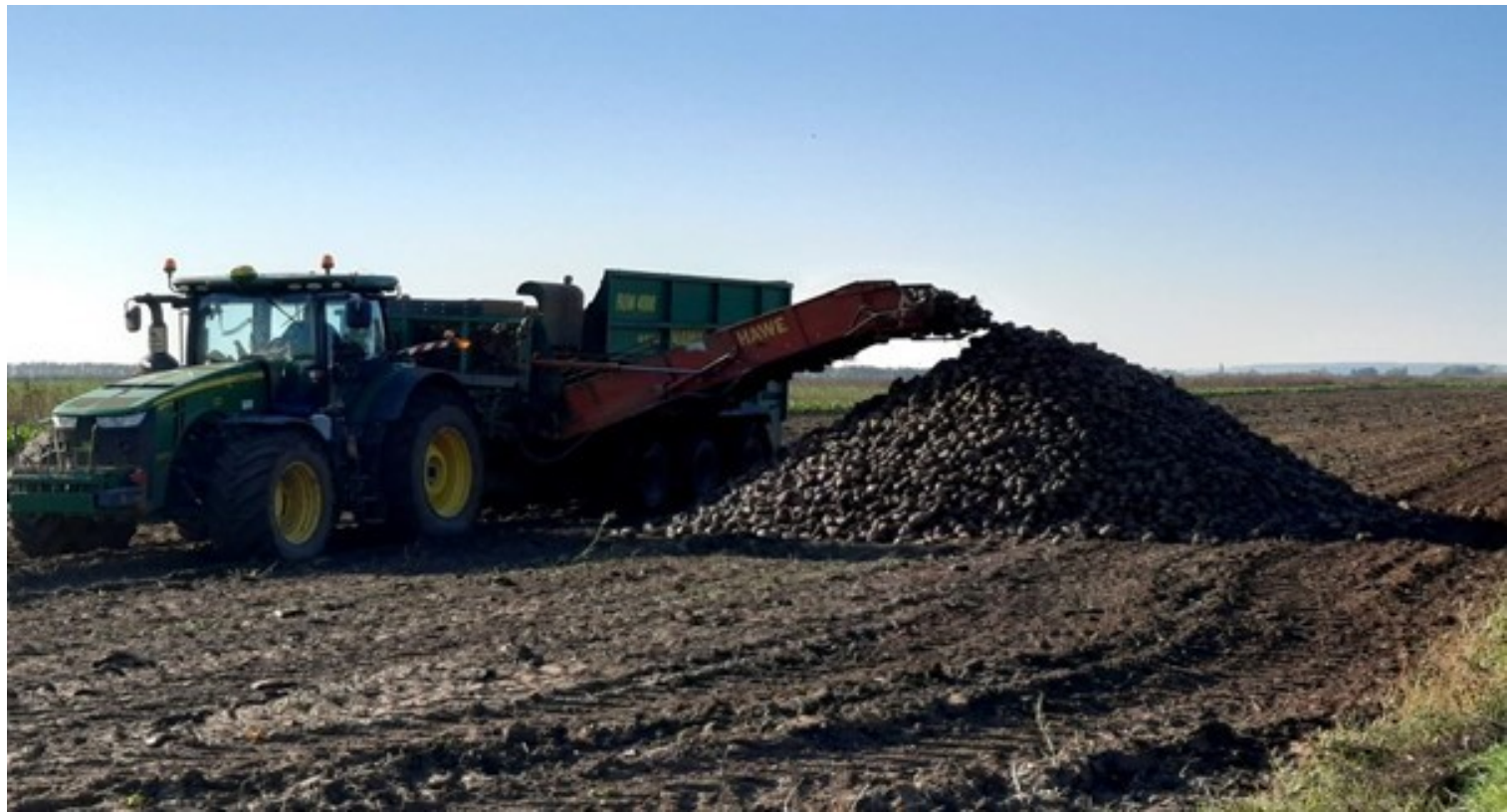

Figure 3 Collecting sugar beet yield on the field. Source: Pol'noinfo (2021). 
Du Pont's return decomposition provides two theoretical variants, the decomposition of return on assets (ROA) and the decomposition of return on equity (ROE). In company practice, the exclusive use of equity capital is relatively rare. External sources in the capital structure affect the final performance of the company and cause the distinguished ROA and ROE values. The share of debt on the total capital is important, determining the intensity of leverage. Therefore, the basic Du Pont equation is further expanded, allowing the second form of decomposition (Kotulič et al., 2010):

$$
R O E=\frac{E A T}{\text { Equity }} * \frac{\text { Assets }}{\text { Assets }}=\frac{E A T}{\text { Assets }} * \frac{\text { Assets }}{\text { Equity }}
$$

Where:

EAT - earnings after taxes; EAT/Asset - return on assets; Assets/Equity - leverage.

The equation for return on equity can be transformed using different categories of profit - earnings before interest and taxes (EBIT), earnings before taxes (EBT), and earnings after taxes (EAT). The following calculation can be expressed as (Holečková and Grunwald, 2001):

$$
\begin{aligned}
& R O E=\frac{E A T}{E q u i t y} * \frac{A s s e t s}{A s s e t s} * \frac{E B I T}{E B I T} * \frac{E B T}{E B T}=\frac{E B I T}{\text { Assets }} * \frac{E B T}{E B I T} * \frac{\text { Assets }}{\text { Equity }} * \\
& \frac{E A T}{E B T}
\end{aligned}
$$

From that relationship, it follows that the return on equity may be broken down into:

EBIT/Assets - BEP ratio (basic earning power) or return on total capital; EBT/EBIT - interest burden ratio (interest rate reduction of profit), Assets/Equity - leverage, EAT/EBT tax burden ratio (tax reduction of profit).

From these relations, it is clear that the ROE is affected by the return on total assets, taxation, and the level of debt in a company. The impact of indebtedness on the return on equity is expressed by the two above-mentioned factors: interest rate reduction of profits and financial leverage, which are acting in a contradictory way. The ratios used in the analysis are the following:

$$
\begin{aligned}
& \text { Return on equity }(R O E)=\frac{E A T}{\text { Equity }} * 100 \\
& \text { EAT on ha of area LPIS }=\frac{E A T}{\text { Agricultural area in ha }} \\
& \text { Equity on ha of area LPIS }=\frac{\text { Equity }}{\text { Agricultural area in ha }} \\
& \text { Indebtedness }=\frac{\text { Total debt }(\text { including accruals })}{\text { Total capital }} * 100 \\
& \text { Financial leverage }=\frac{\text { Total capital }}{\text { Equity }} \\
& \qquad B E P=\frac{E B I T}{\text { Total assets }} * 100
\end{aligned}
$$

To be able to evaluate the companies, the basic descriptive statistics are used:

- $\quad$ lower quartile - includes the lower 25\% ascending values of the statistical character,

- $\quad$ median - the mean value, includes the lower 50\% ascending values of the statistical character,

- upper quartile - includes the upper $25 \%$ of ascending values of the statistical character.
In the case of examining 1000 companies, if the value of ROE in a given year reached 5\% in the lower quartile, $25 \%$ of the companies with the lowest results would reach ROE up to $5 \%$. The remaining 750 enterprises reached ROE more than 5\%. Analogically, it can be applied to the median and the upper quartile. The distribution of the results into quartiles was similarly used in the comparison of financial ratios of Slovak sugar factories (Lukáč, 2020).

For evaluation of whether the company can increase its profitability by increasing the level of debt, we use the Neumaiers model. The model is based on the decomposition of the ROA, with the EBIT in the nominator and the total assets in the denominator. In the paper, we adjusted the terminology used by Neumaier to present the currently used abbreviations (e. g. profit replaced by EBT - earnings before taxes). Neumaier's expressed the ROE as a function of:

$$
\begin{aligned}
& \text { ROE }=\frac{E A T}{E q u i t y}=\frac{E A T}{E B T} * \frac{\text { Assets }}{\text { Equity }} *\left[\frac{E B I T}{\text { Assets }}-\frac{\text { Interests }}{\text { Borrowings }} *(1-\right. \\
& \left.\left.\frac{\text { Equity }}{\text { Assets }}-\frac{\text { Debt }}{\text { Assets }}\right)\right] \\
& \frac{\text { EBIT }}{\text { Assets }}>\frac{\text { Interests }}{\text { Borrowings }} *\left[1-\frac{\text { Debt }}{\text { Assets }}\right]
\end{aligned}
$$

In the comparison of the BEP ratio with the interest rate, the company paid for borrowed capital (debt), while the interest rate was reduced aliquotly. If the relationship is valid (Kotulič et al., 2010), then the company can be in debt. If the sign is opposite, it is not worthy for the company to be indebted. If the sign is equal, then ROE does not depend on indebtedness. For the cost of debt in the analysis, the agreed average annual interest rate reported by the NBS in 2017 for total loans to non - financial corporations was used. Its value of $2.4070 \%$ was used as a constant, based on the Neumairs methodology.

\section{Statistical Analysis}

We used the Statgraphics Centurion 19 software (produced by Statgraphics Technologies, Inc., Virginia).

In the first step, we tested the normality of data by the Shapiro-Wilk test and the goodness of fit test. The normality was tested in both groups (producers and nonproducers of sugar beet). The Shapiro-Wilk test (Shapiro and Wilk, 1965) is based on comparing the quantiles of the fitted normal distribution to the quantiles of the data. The goodness of fit test (Stephens, 1974) is a special case of the Kolmogorov-Smirnov test for testing the normality of the distribution. Data are standardized and compared with the normal distribution. If the $p$-value of the Shapiro-Wilk test and the goodness of fit test is less than 0.05 , we reject that data have the normal distribution with 95\% confidence. The nonparametric test, the Mann - Whitney W test, is further used for testing hypotheses.

The Mann - Whitney W (Mann and Whitney, 1947) test is used to compare the medians of selected groups, the sugar beet producers, and the non-producers. This test is constructed by combining the two groups, sorting the data from smallest to largest, and comparing the average ranks of the two groups in the combined data. If the $p$-value is less than 0.05 , there is a statistically significant difference between the medians at the $95.0 \%$ confidence level. The test is used for analyzing the statistically significant differences of ratios ROE and indebtedness between the selected groups. 


\section{RESULTS AND DISCUSSION}

Sugar beet is an important crop in Europe, with the production of around 120 million tones in 2018, representing almost $45 \%$ of the world's production (FAOSTAT, 2019). Sugar beet is grown in our conditions only to obtain sucrose, while its cultivation contributes to the by-products of its processing (slices, sweetened cuttings, molasses) as well as to certain payments in feed balances. (Bojňanská et al., 2011; Camara-Salim et al., 2021; Mujumdar, 2014). The year $2017 / 18$ was the first year in the sugar sector after the abolition of quotas. This has been reflected in record-breaking results in the amount of sugar produced in the EU. The authors Buysse et al. (2007) dealt with farm-based modeling of the EU sugar reform. Simulation results from a sample of Belgian sugar beet farms show that the sugar CMO (common market organization) reform includes different supply and income effects across farms depending on their share of out-ofquota sugar beet relative to their total beet supply and their quota rent. In Slovakia, the abolition of quotas has not significantly affected sugar beet cultivation. According to the data of the Statistical Office (SO) of SR, the total sugar beet harvested area in 2017 was increased, but only by $4.2 \%$ (22.38 thous ha). With an average yield of $55.00 \mathrm{t}$ per ha, sugar beet production achieved 1230.79 tones, from which 179.5 thous. tons of sugar were produced. In 2017, the yearon-year price of sugar beet decreased by $9.5 \%$ to 24.61 EUR/t (including subsidies) (Meravá, 2019).

Theoretical studies suggest that subsidies may have a positive impact on farm production and at the same time a negative impact on farm productivity (Kozáková et al., 2014). Inefficiency in sugarbeet production results in a shortfall of potential revenues not only for producers but also for landlords and processors (Wu et al., 2003). Support of business can bring along the risk of government failure in the form of misuse of such help by its beneficiaries for their enrichment (Prochazkova et al., 2015).

Not only the production quotas but also the system of export licenses outside the European market has been terminated. The minimum price for sugar beet and the reference price for sugar has been abolished (Zdráhal et al., 2020). In the analysis of the relationship between sugar prices according to the International Sugar Organization (ISO) and sugar prices in selected stock exchanges (USA, UK, India, Brazil, Mexico, China, Russia), the impact of the world price of sugar on prices in individual markets (except for Russia) has been pointed out (Smutka et al., 2019).

The abolition of the sugar quota in 2017 constitutes a turning point for the sugar sector in the European Union. Domestic sugar prices are increasingly linked to world market prices, which used to be far below the EU's in the past. Therefore, questions arise about the EU sugar sector's response to the new market situation without quota and whether sugar beet farming will remain profitable in the future (Wimmer and Sauer, 2020).

The price of sugar beet affects the profitability of its cultivation, as well as the overall profitability of a company. Business owners are primarily interested in the results of return on equity. The owners and investors usually demand the profit on deposited capital to be higher in comparison to other potential investment abilities (e.g. buying bonds, depositing money in financial institutions) (Tóth et al., 2019; Klieštik and Valášková, 2013). The cost of capital is the minimum rate of recoverability which a company must generate to satisfy its creditors, owners, and other providers of capital because otherwise, they will invest elsewhere (Pratt and Grabowski, 2010). In the case of loans, the company must be able to meet the requirements of debt providers by paying interest. According to the Van Binsbergen et al. (2010), the cost of foreign capital is a complex variable representing the cost of debt capital, which is a tax-deductible expense, and it corresponds to the required yield of a creditor taking into account risks and costs of lost opportunities. Therefore, it is desirable for the owners that the return on total capital (BEP) is greater than the cost of debt (represented by the interest rate).

Models of quantification of capital costs and capital structure are solved by many authors (Klieštik and Valášková, 2013; Grabowski, 2009; Porras, 2011; Vo, 2021).

Kotulič et al. (2010) explain the positive and negative leverage as follows:

- positive leverage - if the cost of debt (interest rate on invested debt sources) is lower than the return on total capital, ROE increases as the company's indebtedness increases.

- negative leverage - if the cost of debt (interest rate on invested debt sources) is higher than the return on total capital, with the company's increasing debt, the ROE decreases.

Although strong companies with prospects for prosperity are gradually emerging in the sugar industry, most economic and financial indicators have recorded average negative trends. The problems are caused by the high price of the raw material and the low possibility of selling sugar (Suhr and Schulze, 2003).

\section{Return on equity (ROE)}

Return on cost and return on equity are important factors from the financial and economic point of view according to Kozáková et al. (2014) and Greer et al. (2008). The authors compared selected managerial and financial indicators between organic and conventional production in Slovakia. They state that according to the theory, organic farms are less profitable and therefore the product should be more subsidized when compared to conventional farms. Higher subsidies for organic farms successfully compensate lower revenues and therefore the motivation for the owner to focus on organic farming is not lower than to focus on conventional farming. In 2017, sugar beet producers in Slovakia achieved a lower return on equity (ROE) than nonproducers of sugar beet (Table 1). The data were tested by the Shapiro-Wilk test (Shapiro and Wilk, 1965), the goodness of fit test (Stephens, 1974), and the Mann Whitney W test (Mann and Whitney, 1947) in both selected groups. The results of $\mathrm{P}-$ values of the Shapiro Wilk test and the goodness of fit test were lower than 0.05 in each selected group for the ratio ROE. As the normality of data was not approved with 95\% confidence, we used the Mann - Whitney W test in further analysis. The $p$-value of the Mann - Whitney W - test is 0.00180413 , which was lower than 0.05 . 
Table 1 Return on equity of agricultural companies in 2017.

\begin{tabular}{cccccc}
\hline Ratio & Companies & Count & Lower Quartile & Median & Upper Quartile \\
\hline ROE & SB producers & 132 & $-1.72 \%$ & $1.13 \%$ & $5.67 \%$ \\
ROE & SB non-producers & 1285 & $-0.51 \%$ & $3.42 \%$ & $15.19 \%$ \\
\hline
\end{tabular}

Note: SB - sugar beet. Source: Information letters of the MARD SR; own processing.

Table 2 Values of EAT, equity in EUR per ha p.p. for and indebtedness in \% in 2017.

\begin{tabular}{cccccc}
\hline Ratio & Companies & Count & Lower Quartile & Median & Upper Quartile \\
\hline EAT/ha & SB producers & 132 & -33.59 & 16.05 & 71.31 \\
& SB non-producers & 1285 & -2.34 & 24.60 & 86.81 \\
Equity/ha & SB producers & 132 & 819.32 & 1490.92 & 2155.60 \\
& SB non-producers & 1285 & 289.69 & 700.48 & 1471.86 \\
Indebtedness & SB producers & 132 & $23.85 \%$ & $44.97 \%$ & $67.24 \%$ \\
& SB non-producers & 1285 & $32.43 \%$ & $57.26 \%$ & $80.39 \%$ \\
\hline
\end{tabular}

Note: SB - sugar beet. Source: Information letters of the MARD SR; own processing.

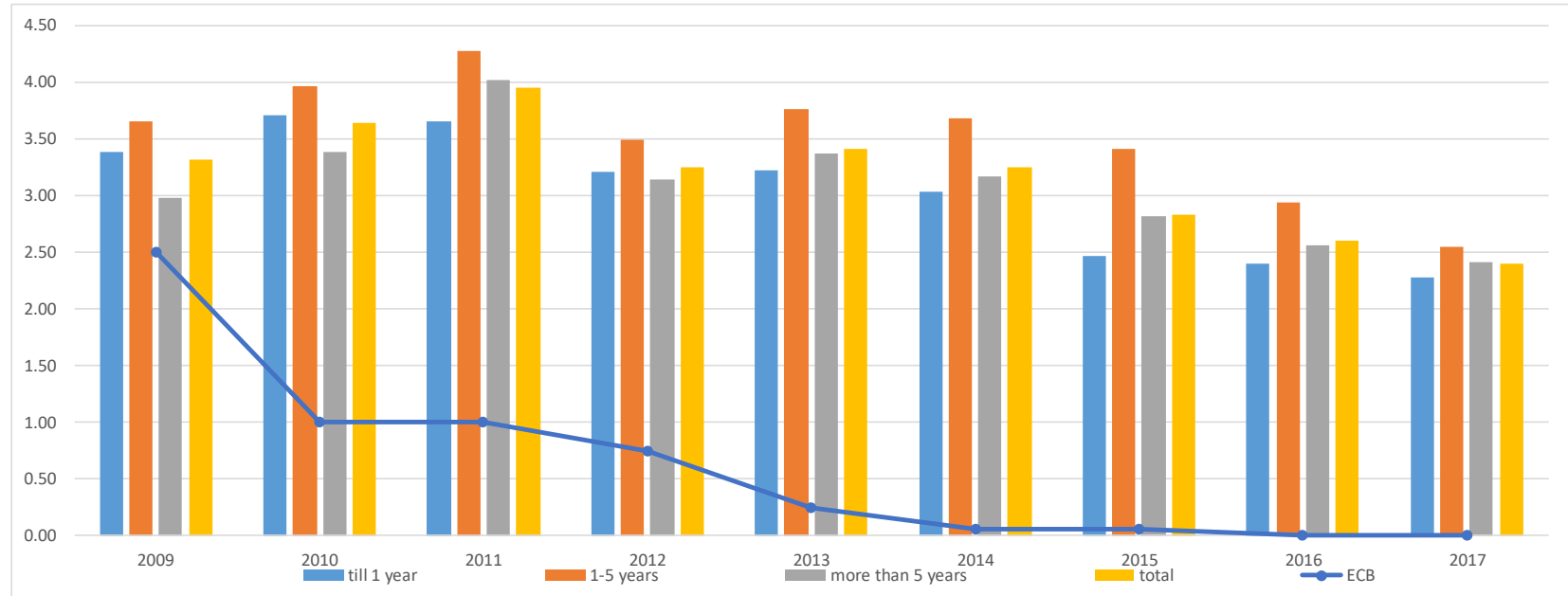

Figure 4 Development of interest rates (\%) on all types of loans in non-financial companies (December 31, 2020). Source: NBS (2020), own processing.

It means there were statistically significant differences between the ratio ROE in our selected groups (sugar beet producers and non-producers) at the $95.0 \%$ confidence level. It means we rejected the $\mathrm{H} 0$ hypothesis. It can be explained by the lower profit per ha, but also by the lower indebtedness of sugar beet producers. In general, the profitability of all agricultural companies is low. The exception is $25 \%$ of companies in the upper quartile of nonproducers of sugar beet. These companies achieve a three times higher return on equity than the sugar beet producers.

There are more reasons why sugar beet producers achieved lower ROE values:

1. The differences in ROE are not only due to the higher profit (EAT) per ha of non-producers of sugar beet. The median value (EAT) is 16.05 EUR/ha for sugar beet producers and 24.6 EUR/ha for non-producers of sugar beet. The reason is also the fact that sugar beet producers have a higher need for equity per hectare. In the median value, it is only 700 EUR/ha for nonproducers of sugar beet and more than twice as much, 1490 EUR/ha, for sugar beet producers.

2. Sugar beet producers show lower values of the degree of indebtedness in all quartiles, which means they use more equity. The results of our analysis are presented in Table 2.
Each type of capital has a price that a company must pay for its use. For loans, the price is the interest rate. Interest is paid from earnings before taxes, in the case of a company's bankruptcy, the creditors are paid off earlier than the owners. It causes a lower risk of debt, and therefore a lower required return (Tóth et al., 2019). The advantage of financing the needs of a company through debt is the use of a cheaper type of business capital. Interest on borrowed capital is tax-deductible and the debt is less risky than equity, and therefore, it is considered to be cheaper.

The problem of capital taxation efficiency of agricultural business in the Slovak Republic was assessed by Andrejovská et al. (2019). The authors state that to keep costs as low as possible, the companies try to optimize their capital structure. Corporate tax is the cost of equity financing, and this cost is often higher than other costs, such as in form of interests, which are a tax-deductible item, thereby causing a reduction in the tax base, so-called interest tax shield. A more complex overview of taxationrelated aspects of dividends and their development is provided in Krajčírová et. al (2019).

\section{Evolution of interest rates}

However, the growth of the agriculture sector and agricultural firms is highly constrained by their access to finance (O'Toole et al., 2014). 
Table 3 Financial leverage and BEP in 2017.

\begin{tabular}{cccccc}
\hline Ratio & Companies & Count & Lower Quartile & Median & Upper Quartile \\
\hline Financial leverage & SB producers & 132 & 1.31 & 1.82 & 3.05 \\
& SB non-producers & 1285 & 1.48 & 2.34 & 5.10 \\
BEP & SB producers & 132 & $-0.57 \%$ & $1.33 \%$ & $4.09 \%$ \\
& SB non-producers & 1285 & $0.32 \%$ & $2.42 \%$ & $6.49 \%$ \\
\hline
\end{tabular}

Note: SB - sugar beet. Source: Information letters of the MARD SR; own processing.

Global trends in interest rates were also addressed by Del Negro et al. (2019) and Borio et al. (2017).

The trend in the world's real interest rate fluctuated close to $2 \%$ for more than a century but has dropped significantly over the past three decades. This decline has been common among advanced economies, as trends in real interest rates across countries have converged over this period. It was driven by an increase in the convenience yield for liquidity and by lower global economic growth (Del Negro et al., 2019).

The current trend of low-interest rates of the ECB has been reflected in lowered interest rates of commercial banks. Low interest rates may encourage companies to use a higher share of debt for business financing, and thus increase the return on equity through the financial leverage for a certain period. Interest rates for businesses have fallen significantly.

According to NBS data (Figure 4), since 2009, the interest rates on all types of loans have fallen. At the beginning of 2009, the European Central Bank (ECB) started lowering the rate of main refinancing operations from the original $2.5 \%$ (1.1.2009) to $0.00 \%$ till March 16, 2016, and nowadays (February 2021).

These measures of the ECB have been objected to supporting the growth of the Euro Area economy while avoiding a fall into a deflationary spiral, as inflation oscillated around zero (Rábek et al., 2013b). Low interest rates should motivate businesses, but also the population, to take out more loans. In the period from 2009 to 2017, the interest rates decreased, with the lowest rates of commercial banks for loans maturing within 1 year (Figure 4). The average interest rate on loans in 2017 was $2.4070 \%$ and we considered it in our calculations.

Lin and He (2020) investigated the effect of a targeted easing (TE) monetary policy in boosting lending to the agriculture sector. Using longitudinal data of listed Chinese firms between 2012 and 2017, they documented that the TE implementation is effective in increasing loan levels of agriculture businesses relative to non-agricultural firms.

\section{Financial leverage}

The problem of the different impact of the leverage effect on the default risk of small and large firms was solved by Cathcart et al. (2020).

Companies can increase the return on equity by increasing the debt ratio (indebtedness), which means using financial leverage. For proper use, the condition that the return on total capital (BEP) is greater than the cost of borrowed capital (debt) has to be met. The results of the analysis of financial leverage effect on agricultural companies are presented in Table 3.

In 2017, 25\% of sugar beet producers with the lowest value of financial leverage (lower quartile) reached a value of up to 1.31, and non-producers of sugar beet of up to 1.48 .
The median values for sugar beet producers are at 1.82, and non-producers at 2.34 level.

However, 25\% of sugar beet non-producers achieved a result of financial leverage of up to 5.10, compared to 3.05 in the case of sugar beet producers. These companies can better use the effect of debt financing. The result also referred to the higher level of indebtedness of sugar beet non-producers' companies (see Table 2). The data were tested by the Shapiro-Wilk test, the goodness of fit test, and the Mann - Whitney W test in both selected groups. The result of $\mathrm{P}$ - values of the Shapiro-Wilk test and the goodness of fit test was lower than 0.05 in each selected group, with 95\% confidence. Therefore, we rejected the assumption that data of ratio indebtedness had a normal distribution with 95\% confidence. As the distribution was not normal, we used the Mann - Whitney W test for testing hypotheses. The $p$-value of the Mann - Whitney W test for the ratio of indebtedness is 0.000564923 , which means less than 0.05 . There was a statistically significant difference between the ratio of Indebtedness in our two groups (sugar beet producers and non-producers) at the $95.0 \%$ confidence level. It means we rejected the H0 hypothesis. To use the leverage effect, it is necessary to assess the level of return on total capital. Similarly, as in the case of ROE, sugar beet non-producers achieved higher values of BEP ratios in all quartiles (Table 3).

An increase in the return on equity can be reached if the return on total capital is higher than the cost of debt. We considered the cost of debt to be the average interest rate in 2017, 2.4070\%. According to the Neumair model, we multiplied it with [1-(liabilities/assets)].

In 2017, 60 companies from the group of sugar beet producers met the requirement, which represents $53.1 \%$ of companies. In the group of non-producers of sugar beet, 788 companies met the requirement, which represents $63.3 \%$ of companies. The companies which meet the requirement may increase the share of debt in total capital and would increase their return on equity. Beck and Demirguc-Kunt (2008) found that small firms used less external finance, especially bank loans when analyzing firm-level data of small and large firms across 48 countries. They also showed that large credit-constrained firms could more easily increase external sources of finance than small firms.

\section{CONCLUSION}

In 2017, the CAP production quotas for sugar were abolished, resulting in the increased sugar production in the EU. The increase in production leads to pressure on the price decrease and may threaten the competitiveness of sugar beet producers and growers. Therefore, the farmers not only have to pay attention to the production levels but also to finding ways to increase the profitability of the business.

One of the options is the use of the leverage effect, which results in the potential increase in the return on equity. The 
leverage effect can be applied if the return on total capital is higher than the cost of debt. Then, by increasing the indebtedness, the company will increase the return on equity. Firms that do not achieve a sufficiently high return on total capital should try to reduce the level of indebtedness, which would also have a positive impact on the return on equity, through the effect of financial leverage. Almost $53.1 \%$ of sugar beet producers in Slovakia can positively influence their return on equity by increasing the level of indebtedness.

In 2017, the return on equity of sugar beet producers in Slovakia reached lower results in comparison to sugar beet non-producers. In general, the return on equity for all agricultural companies is at a low level, except for $25 \%$ of non-producers of sugar beet in the upper quartile (with the highest values). These companies achieved a return on equity of $15.19 \%$, which is three times higher in comparison to sugar beet producers in this quartile. The differences in return on equity are explained by the lower level of equity per ha and thus higher indebtedness of non-producers of sugar beet.

We recommend the sugar beet producers increase the level of indebtedness for two reasons.

Firstly, interest rates are at a low level and the indebtedness of sugar beet producers is lower in comparison to non-producers of sugar beet.

Secondly, if the cost of debt in the company is below the return on total capital (BEP), an increase in indebtedness increases return on equity.

The leverage effect is a mathematical matter that can be applied in any company. However, it should be noted that the managers have to be careful when increasing the level of indebtedness. The negative aspect of debt financing is the fact that from a certain level of debt, there is a higher risk of financial distress, which can lead to a company's bankruptcy.

\section{REFERENCES}

Andrejovská, A., Buleca, J., Puliková, V. 2019. Capital taxation efficiency of agricultural businesses in the Slovak Republic. Potravinarstvo Slovak Journal of Food Sciences, vol. 13, no. 1, p. 572-580. https://doi.org/10.5219/1135

Bartošová, V. 2005. Optimalizácia finančnej štruktúry podniku (Optimisation of financial structure of company). Žilina, Slovak republic : Žilinská univerzita. ISBN 80-8070404-X. (in Slovak)

Beck, T., Demirguc-Kunt, A. 2006. Small and medium-size enterprises: Access to finance as a growth. Journal of Banking and Finance, vol. 30, no. 11, p. 2931-2943. https://doi.org/10.1016/j.jbankfin.2006.05.009

Bojňanská, T., Bennár, M., Frančáková, H., Tokár, M. 2011. Process of obtaining of sugar from sugar beet and influence on its quality. Potravinarstvo Slovak Journal of Food Sciences, vol. 5, no. 1, p. 1-4. https://doi.org/10.5219/122

Borio, C. E., Disyatat, P., Juselius, M., Rungcharoenkitkul, P. 2017. Why so low for so long? A long-term view of real interest rates. Bank for International Settlements Working Papers, no. 685. p. 1-73.

Brealey, R. A., Myers, S. C. 1992. Teorie a praxe firemních finance (Theory and practice of corporate finance). Translated by Tůma, Z., Tůma, M. Prague, Czech Republic : Victoria Publishing, 971 s. ISBN 80-85605-24-4. (in Slovak)

Buysse, J., Fernagut, B., Harmignie, O., Henry de Frahan, B., Lauwers, L., Polomé, P., Van Huylenbroeck, G., Van Meensel,
J. 2007. Farm-based modelling of the EU sugar reform: impact on Belgian sugar beet suppliers. European Review of Agricultural Economics, vol. 34, no. 1, p. 21-52. https://doi.org/10.1093/erae/jbm001

Camara-Salim, I., Conde, P., Feijoo, G., Moreira, M. T. 2021. The use of maize stover and sugar beet pulp as feedstocks in industrial fermentation plants - An economic and envidonmental perspective. Cleaner Environmental Systems, vol. 2, no. 100005, $36 \quad$ p. https://doi.org/10.1016/j.cesys.2020.100005

Cathcart, L., Dufour, A., Rossi, L., Varotto, S. 2020. The differential impact of laverage on the default risk of small and large firms. Journal of Corporate Finance, vol. 60, no. 101541, 74 p. https://doi.org/10.1016/j.jcorpfin.2019.101541

Čierna, Z., Rábek, T. 2012. Možnosti zvyšovania rentability vlastného kapitálu pôsobením finančnej páky v pol'nohospodárskych podnikoch (Increasing the return on equity by financial leverage in agricultural enterprises). Ekonomika pol'nohospodárstva, vol. 12, no. 2, p. 31-40. (in Slovak)

Del Negro, M., Giannone, D., Giannoni, M. P., Tambalotti, A. 2019. Global trends in interest rates. Journal of International Economics, vol. 118, p. 248-262.

FAOSTAT. 2019. Crop Statistics. Available at: http://www.fao.org/faostat/en/\#data.

Grabowski, R. J. 2009. Cost of Capital Estimation in the Current Distressed Environment. The Journal of Applied Research in Accounting and Finance, vol. 4, no. 1, p. 31-40.

Greer, G., Kaye-Blake, W., Zellman, E., Parsonson-Ensor, C. 2008. Comparison of the financial performance of Organic and conventional farms. Journal of Organic Systems, vol. 3, no. 2, p. 18-28.

Holečková, J., Grunwald, R. 2001. Finanční analýza a plánovaní podniku (Financial analysis and planning in company). $2^{\text {nd }}$ ed. Prague, Czech Republic : VŠE, 197 s. ISBN 80-7079-587-5.

Holúbek, I. 2011. Náklady a výnosy cukrovej repy v pol'nohospodárskom podniku Tapos, s.r.o. po reforme SOT (Costs and yields of sugar beet in the Agricultural Company Tapos Ltd. after the CMO reform). Listy cukrovarnické a repařské, vol. 127, no. 9-10, p. 292-296. (in Slovak)

Hrdý, M., Krechovská, M. 2013. Podnikové financie v teórii a praxi (Corporate finance in theory and practice). $1^{\text {st }}$ ed. Prague, Czech republic : Wolters Kluwer ČR, 268 s., ISBN 978-80-7478-011-0. (in Slovak)

Janíček, D. 2019. Cukrovarnícka kampaň 2018/2019 na Slovensku (Campain of sugar factories in 2018/2019 in SR). Listy cukrovarnické a řepařské, vol. 133, no. 5, p. 178-179.

Klieštik, T., Valášková, K. 2013. Models of capital costs quantification. Journal of Advanced Research in Management, vol. 4, no. 1, p. 5-19.

Kotulič, R., Király, P., Rajčániová, M. 2010. Finančná analýza podniku (Financial analysis of company). $2^{\text {nd }}$ ed. Bratislava, Slovak republic : Iura edition, 238 s. ISBN 978-808078-342-6. (in Slovak)

Kozáková, J., Lančarič, D., Savov, R., Tóth, M. 2014. Organic and conventional production in Slovakia: Comparison of selected managerial and financial indicators. Potravinarstvo Slovak Journal of Food Sciences, vol. 8, no. 1, p. 254-260. https://doi.org/10.5219/386

Krajčírová, R., Ferenzi Vaňová, A., Munk, M. 2019. What Is Relationship between Profits and Dividends in Agricultural Legal Entities?. AGRIS on-line Papers in Economics and Informatics, vol. 11, no. 1, p. 55-65. https://doi.org/10.7160/aol.2019.110106 
Lin, C., He, L. 2020. Targeted monetary policy and agriculture business loans. The North American Journal of Economics and Finance, vol. 54, no. 101290, p.1-13. https://doi.org/10.1016/j.najef.2020.101290

Lukáč, J. 2020. Komparácia finančných indikátorov slovenských cukrovarov (Comparison of financial indicators of Slovak sugar factories). Listy cukrovarnické a řepařské, vol. 136, no. 3, p. 126-130. (in Slovak)

Mann, H. B., Whitney, D. R. 1947. On a Test of Whether one of Two Random Variables is Stochastically Larger than the Other. Annals of Mathematical Statistics, vol. 18, no. 1, p. 5060. https://doi.org/10.1214/aoms/1177730491

Meravá, E. 2019. Cukrová repa, cukor (Sugar beet, sugar). NPPC - VÚEPP. ročník XIII, p. 5-15. Available at: http://www.vuepp.sk/dokumenty/komodity/2019/Cukor06_19 _v2.pdfhttp://www.vuepp.sk/dokumenty/komodity/2019/Cuk or06_19_v2.pdf. (in Slovak)

Modigliani, F., Miller, M. H. 1958. The cost of capital, corporation finance and the theory of investment. American Economic Review, vol. 48, no. 3, p. 261-97.

Mujumdar, A. S. 2014. Handbook of Industrial Drying. $4^{\text {th }}$ ed. Boca Raton, Florida, USA : CRC Press, p. 1348. ISBN 9780429169762. https://doi.org/10.1201/b17208

NBS. 2020. Úvery (Loans). Available at https://www.nbs.sk/sk/statisticke-udaje/financne-

institucie/banky/statisticke-udaje-penaznych-financnych-

institucii/uvery. (in Slovak)

Neumaierová, I., Neumaier, I. 1996. Úvaha o optimálni zadluženosti (Consideration of optimal indebtedness). Finance a úvěr, vol. 46, p. 15. Available at: http://journal.fsv.cuni.cz/storage/2172_199601in.pdfhttp://jou rnal.fsv.cuni.cz/storage/2172_199601in.pdf. (in Slovak)

O'Toole, C. M., Newman, C., Hennessy, T. 2014. Financing constraints and agricultural investment: Effects of the Irish financial crisis. Journal of Agricultural Economics, vol. 65, no. 1, p. 152-176.

Pol'noinfo. 2021. Available at: https://polnoinfo.sk/.

Porras, E. R. 2011. The Cost of Capital. $1^{\text {st }}$ ed. New York, USA : Palgrave Macmillan, 246 p. ISBN 978-0-230-29767-8.

Pratt, S. P., Grabowski, R. J. 2010. Cost of Capital in Litigation - Applications and Examples. 4th ed. New Jersey, USA : John Wiley and Sons Inc, 301 p. ISBN 978-1-11920068-0.

Prochazkova, P. T., Krechovska, M., Lukas, L. 2015. Effectiveness of entrepreneurship policies: some evaluation research perspectives. Amfiteatru Economic Journal, vol 17, no. 39, p. 706-722. Available at: http://hdl.handle.net/10419/168943.

Rábek, T., Strápeková, Z., Tóth, M. 2013a. Náklady kapitálu a finančný leverage $\mathrm{v}$ pol'nohospodárskych podnikoch na Slovensku (Cost of capital and financial leverage in agricultural enterprises in Slovakia). Ekonomika pol'nohospodárstva, vol. 13, no. 4, p. 78-89. (in Slovak)

Rábek, T., Strápeková, Z., Tóth, M. 2013b. Využitie finančnej páky V podmienkach slovenského pol'nohospodárstva (Utilization of financial leverage in Slovak agricultural primary production). Trendy v podnikání, vol. 3, no. 4, p. 52-57. (in Slovak)

Rábek, T., Strápeková, Z., Tóth, M., Holúbek, I. 2018.Vplyv zadíženosti na rentabilitu pol'nohospodárskych podnikov na Slovensku (Impact of indebtedness on the profitability of agricultural enterprises). Trendy v podnikání, vol. 8, no. 4 p. 412. https://doi.org/10.24132/jbt.2018.8.4.4_12 (in Slovak)

Rezbová, H., Belová, A., Škubna, O. 2013. Sugar beet production in the European Union and their future trends.
AGRIS on-line Papers in Economics and Informatics, vol. 5, no. 4, p. 1-14.

Robischek, A. A., Myers, S. C. 1966. Problems in the Theory of Optimal Capital Structure. The Journal of Financial and Quantitative Analysis, vol. 1, p. 1-35. https://doi.org/10.2307/2329989

Ross, S.A. 1977. The Determination of Financial Structure: The Incentive-Signalling Approach The Bell Journal of Economics, vol. 8, no. 1, p. 23-40. https://doi.org/10.2307/3003485

Shapiro, S. S., Wilk, M. B. 1965. An analysis of variance test for normality (complete samples). Biometrika, vol. 52, no. 3-4, p. 591-611. https://doi.org/10.1093/biomet/52.3-4.591

Smutka. L., Rumánkova, L., Pulkrábek, J., Krajčírová, R. 2019. Tvorba ceny cukru na světových trzích v závislosti na světové ceně cukru (Creation of sugar prices in the world markets depending on the market price of sugar). Listy cukrovarnícke a řepařské, vol. 135, no 12, p. 408-411. (in Slovak)

Stephens, M. A. 1974. EDF Statistics for Goodness of Fit and Some Comparisons. Journal of the American Statistical Association, vol. 69, no. 347, p 730-737. https://doi.org/10.2307/2286009

Suhr, M. R., Schulze, B. C. 2003. Technology in use in the modern beet sugarfactory. International Sugar Journal, vol. 105, no. 2, p. 52-58.

Tóth, M., Holúbek, I., Boháčiková, A. 2017. Vplyv pestovania cukrovej repy na ekonomickú výkonnost' fariem v Slovenskej republike (Impact of sugar beet production on the economic performance of farms in the Slovak Republic). Listy cukrovarnicke a řepařské, vol. 133, no. 11, p. 344-350.

Tóth, M., Holúbek, I., Strápeková, Z., Serenčéš, P., Rábek, T. 2019. Finančný manažment a podnikatel'ské riziko v pol'nohospodárstve Slovenskej republiky (Financial analysis and business risk in agriculture of SR). Nitra, Slovak republic : Slovenská pol'nohospodárska univerzita v Nitre, 187 s. ISBN 978-80-552-2075-8. (in Slovak)

Tóth, M., Pokrivčák, J. 2019. Ekonomické prínosy pestovania cukrovej repy na Slovensku (Economic benefits of sugar beet cultivation in Slovakia). Listy cukrovarnícke a repařské, vol. 135, no. 9, p. 318-321. (in Slovak)

Van Binsbergen, J. H., Graham, J. R., Yang, J. 2010. The cost of debt. The Journal of Finance, vol. 65, no. 6, p. 2089-2136. https://doi.org/10.1111/j.1540-6261.2010.01611.x

Vo, M. T. 2021. Capital structure and cost of capital when prices affect real investment. Journal of Economics and Business, vol. 113, no. 3, p. 105944. https://doi.org/10.1016/j.jeconbus.2020.105944

Wimmer, S., Sauer, J. 2020. Profitability Development and Resource Reallocation: The Case of Sugar Beet Farming in Germany. Journal of Agricultural Economics, vol. 71, no. 3, p. 816-837.

Wu, S., Devadoss, S., Lu, Y. 2003. Estimation and decomposition of technical efficiency for sugarbeet farms. Applied Economics, vol. 35, no. 4, p. 471-484, https://doi.org/10.1080/00036840210161819

Zdráhal, I., Chmelíková, G., Bečvářová, V. 2020. Ziskovost cukrovarnictví v Evropské unii (Profitability of sugar industry in EU). Listy cukrovarnické a řepařské, vol. 136, no. 1, p. 3035. (in Slovak)

\section{Funds:}

This paper is supported by projects VEGA no 1/0338/18 with the title Impact of the Common Agricultural Policy on the mitigation of income risk in Slovak agriculture and factors determining the level of risk of agricultural 
companies, VEGA no 1/0735/21 with the title Role, financial needs and risks of small farms in Slovakia and Demand-oriented research for sustainable and innovative food, no. 313011 V336 called Drive4SIFood.

\section{Acknowledgments:}

We would like to thank MARD SR for data used in the analysis.

\section{Conflict of Interest:}

The authors declare no conflict of interest.

\section{Ethical Statement:}

This article does not contain any studies that would require an ethical statement.

\section{Contact Address:}

Ing. Tomáš Rábek, PhD.*, Slovak University of Agriculture in Nitra, Faculty of Economics and Management, Tr. Andreja Hlinku 2, 94976 Nitra, Slovakia, Tel: +421 37641 4140,

E-mail: tomas.rabek@uniag.sk

ORCID: https://orcid.org/0000-0002-0239-6905
Ing. Andrea Boháčiková, PhD., Slovak University of Agriculture in Nitra, Faculty of Economics and Management, Tr. Andreja Hlinku 2, 94976 Nitra, Slovakia, Tel: +421 37641 4195,

E-mail: andrea.bohacikova@uniag.sk

ORCID: https://orcid.org/0000-0001-5732-7774

doc. Ing. Ivan Holúbek, PhD., Slovak University of Agriculture in Nitra, Faculty of Economics and Management, Tr. Andreja Hlinku 2, 94976 Nitra, Slovakia, Tel: +421 37641 4146,

E-mail: ivan.holubek@uniag.sk

ORCID: https://orcid.org/0000-0001-8489-0394

Ing. Zuzana Strápeková, PhD., Slovak University of Agriculture in Nitra, Faculty of Economics and Management, Tr. Andreja Hlinku 2, 94976 Nitra, Slovakia, Tel: +421 37641 4140,

E-mail: zuzana.strápeková@uniag.sk

ORCID: https://orcid.org/0000-0003-1253-2795

*Corresponding author. 